\title{
Restrukturisasi Sistem Pelatihan Kepemimpinan dalam Membentuk Calon Pemimpin Masa Depan: Pendekatan Studi Literatur
}

\author{
Zahron Helmy, Ahmad Syariful Jamil \\ Balai Pelatihan Pertanian Jambi, Jl. Jambi-Palembang Km 16, Kab. Muara Jambi \\ email : zahronhelmi@gmail.com
}

\begin{abstract}
An Effective leadership is integral part of the effectiveness of a government organization. Therefore, this article aims to explain the study of leadership training system development in order to prepare future leaders. Leadership training for government organizations in Indonesia basically has been a concern for the government for a long time. The evaluation results show that in general the organization of leadership training has been effective. However, leadership training still needs improvement, especially on the impact of training on organizational performance. Training was tend to be considered as cost, it has been yet an investment which could be measured by rate of return. That condition demanded the leadership training institution be able to develop a framework strategy of holistic approach. That approach can be done through: 1) the development of training and education program candidates through talent management; 2) restructuring training education programs through innovative program models, developing institutions and buying leaders and 3) integrating education and training programs with job auctions through the use of talent pool. The integration of the three approaches is expected to produce futer leaders who are reliable and character.
\end{abstract}

Keywords: Evaluation, leadership training, leaders, innovation

\section{Abstrak}

Kepemimpinan yang efektif adalah bagian integral dari efektifitas suatu organisasi pemerintah. Oleh karena itu, artikel ini bertujuan memaparkan mengenai studi pengembangan system pelatihan kepemimpinan dalam rangka mempersiapkan calon pemimpin masa depan. Pelatihan kepemimpinan bagi organisasi pemerintah di Indonesia pada dasarnya telah menjadi konsen pemerintah sejak lama. Hasil evaluasi menunjukkan bahwa secara umum penyelenggaraan pelatihan kepemimpinan sudah efektif. Akan tetapi, pelatihan kepemimpinan masih membutuhkan perbaikan khususnya pada dampak pelatihan terhadap kinerja organisasi. Pelatihan cenderung dianggap sebagai beban biaya, belum sebagai investasi yang dapat diukur tingkat pengembalian. Kondisi tersebut menuntut lembaga pelatihan kepemimpinan dapat mengembangkan kerangka strategi pendekatan secara holistic. Pendekatan tersebut dapat dilakukan melalui: 1) pengembangan calon peserta program pendidikan dan pelatihan melalui manajemen talenta; 2) restrukturisasi program pendidikan pelatihan melalui inovasi model program, pengembangan lembaga dan buying leaders dan 3) Integrasi program pendidikan dan pelatihan dengan lelang jabatan melalui pemanfaatan talent pool. Adanya integrasi dari ketiga pendekatan tersebut diharapkan dapat menghasilkan calon pemimpin masa depan yang handal dan berkarakter.

Kata Kunci: Evaluasi, pelatihan kepemimpinan, pemimpin, inovasi

\section{PENDAHULUAN}

Kepemimpinan yang efektif adalah bagian integral dari efektifitas suatu organisasi pemerintah. Hal ini dikarenakan pemimpin dapat menciptakan budaya organisasi, memperkuat motivasi, memperjelas visi dan misi organisasi serta memimpin organisasi untuk menjadi organisasi yang produktif dan berkinerja tinggi. Studi yang dilakukan oleh Partnership for Public Service (2003) mengindikasikan bahwa kepemimpinan 
merupakan factor utama dalam kepuasan karyawan di tempat kerja dan pada akhirnya dapat meningkatkan kinerja organisasi.

Salah satu metode yang paling banyak ditempuh dalam rangka mempersiapkan calon pemimpin masa depan adalah melalui pelatihan (Amaluis, 2014). (Handayani et al., 2015) menyatakan bahwa pelatihan memiliki keiikutsertaan yang besar di dalam menentukan efektivitas dan efisiensi suatu organisasi. Manfaat lain dari pelatihan yaitu meningkatkan kualitas dan produktivitas, menciptakan sikap, loyalitas dan kerjasama yang lebih menguntungkan dan memenuhi kebutuhan perencanaan SDM di masa yang akan datang (Sulistiyani 2009). Melalui pelatihan tersebut diharapkan dapat melahirkan pemimpin unggul dikemudian hari.

$\begin{array}{ccr}\text { Pentingnya } & \text { peran } & \text { pelatihan } \\ \text { kepemimpinan } & \text { dalam } & \text { rangka } \\ \text { mempersiapkan } & \text { pemimpin } & \text { organisasi }\end{array}$
direspon oleh pemerintah melalui besarnya anggaran yang disediakan dalam rangka melaksanakan pelatihan kepemimpinan dan terdapat kecenderungan yang meningkat. Hal tersebut menjadikan anggaran yang dibutuhkan untuk mencetak para pemimpin organisasi pemerintah di negeri paling besar dibandingkan dengan anggaran pelatihan lainnya. Sebagai gambaran, anggaran yang dibutuhkan untuk menyelenggarakan pelatihan kepemimpinan (Diklatpim) tingkat I, II, III dan IV masing-masing per Angkatan sebesar Rp.1.4 miliar, Rp.1.8 miliar, Rp.885 juta dan Rp.809 juta (PERLAN No 2 Tahun 2018). Besaran biaya tersebut meningkat dibandingkan pada tahun 2014, dimana sebesar Rp. 1.3 miliar. Rp. 1.8 miliar, Rp. 660 juta, dan Rp. 606 juta masing-masing per Angkatan untuk Diklatpim I, II, III dan IV (Perkalan No. 20 Tahun 2013) Kondisi tersebut berbeda dibandingkan dengan anggaran yang dikhususkan untuk pelatihan fungsional seperti penyuluh pertanian yang rata-rata hanya mencapai kurang lebih Rp.120 juta.

Besarnya anggaran pelatihan kepemimpinan tidak selalu berbanding lurus dengan kualitas pemimpin yang dihasilkan. Scwartz et al. (2014) menunjukkan bahwa organisasi pemerintah saat ini mengalami kekurangan pemimpin yang memiliki kompetensi kepemimpinan yang memadai, hanya sekitar $13 \%$ dari organisasi percaya bahwa mereka telah menerapkan program pelatihan kepemimpinan yang efektif. Sama halnya, Leslie (2009) menyatakan bahwa beberapa organisasi mengalami deficit kepemimpinan, dan program pelatihan saat ini relative kurang mampu menghasilkan pemimpin yang handal. Selain itu, kenyataannya bagi masyarakat kinerja pemimpin saat ini jauh dari yang diharapkan oleh masyarakat (Handayani et al., 2015); (Wardani \& Suryono, 2014) .Pemimpin terkesan tidak dibekali dengan kompetensi kepemimpinan inti yang mereka butuhkan untuk mencapai kesuksesan dalam karirnya.

Pada sisi penyelenggaraan, pelatihan kepemimpinan dirasakan banyak kekurangan dan kendala. Kekurangan yang sangat dirasakan dari segi penyelenggaraan pelatihan adalah mengenai materi yang terlalu luas, 
kurangnya kemampuan widyaiswara, sarana dan prasarana pelatihan yang kurang memadai (Sudradjat, 2010), serta evaluasi pasca pelatihan yang kurang representative (Melandari, 2016).

Berbagai keterbatasan tersebut menjadi bahan evaluasi bagi program pelatihan kepemimpinan ke depan. Terlebih lagi, adanya era disrupsi dan agenda perubahan eselonering, menuntut program kepemimpinan untuk dapat lebih meningkatkan efektivitasnya dalam menghasilkan pemimpin yang mampu menyesuaikan terhadap perkembangan zaman.

Pada dasarnya terdapat konsekuensi yang dihadapi lembaga pelatihan kepemimpinan dalam meningkatkan efektivitasnya. Pertama, restrukturisasi program dalam rangka meningkatkan efektivitas akan terasa sulit, ini dikarenakan kekosongan data evaluasi yang kredibel. Belum tersedianya model evaluasi yang dapat mengevaluasi dampak pelatihan terhadap kinerja organisasi (Return on Investment). Kondisi tersebut menyebabkan restrukturisasi program relative tidak memiliki arah yang jelas. Kedua, rigid dan kakunya model program pelatihan kepemimpinan, menyebabkan lembaga pelatihan relative tidak memiliki upaya untuk melakukan inovasi pengembangan model pelatihan kepemimpinan. Oleh karena itu, artikel ini bertujuan memaparkan pengembangan system pelatihan kepemimpinan dalam rangka mempersiapkan calon pemimpin masa depan.

\section{PELATIHAN KEPEMIMPINAN}

Pelatihan kepemimpinan secara umum didefinisikan sebagai program yang secara sistematis didesain dalam rangka meningkatkan pengetahuan, sikap dan keterampilan pemimpin (Day 2000). Pelatihan kepemimpinan bagi organisasi pemerintah di Indonesia pada dasarnya telah menjadi konsen pemerintah sejak lama. Semangat pengembangan pelatihan kepemimpinan diawali dengan dibentuknya Lembaga Administrasi Negara dengan dikeluarkannya Peraturan Pemerintah Republik Indonesia No.30 Tahun 1957 tentang Lembaga Administrasi Negara (LAN) dan Keputusan Presiden Republik Indonesia Nomor 34 tahun 1972 tentang tanggung jawab fungsionil pendidikan dan pelatihan.

Peraturan tersebut menyebutkan bahwa salah satu tugas dan fungsi LAN adalah menyelenggarakan dan mengawasi pendidikan dan latihan pegawai negeri sipil dan/atau calon pegawai negeri sipil. Pada waktu itu, belum ada peraturan yang secara spesifik mengatur terkait pendidikan dan pelatihan kepemimpinan, namun pelatihan tersebut sudah dijalankan oleh masingmasing departemen.

Pada dasarnya pelatihan kepemimpinan bagi Pegawai Negeri Sipil (PNS) yang akan/telah menduduki suatu tingkatan jabatan struktural atau eselon pertama kali dibentuk melalui mekanisme Sekolah Pimpinan Administrasi. Pelatihan tersebut antara lain Sekolah Pimpinan Administrasi Tingkat Dasar (Sepada), Sekolah Pimpinan Administrasi Tingkat Lanjutan (Sepala), Sekolah Pimpinan 
Administrasi Tingkat Madya (Sepadya), Sekolah Pimpinan Administrasi Tingkat Nasional (Sespanas).

Perkembangan selanjutnya, pelatihan kepemimpinan tersebut kemudian digantikan dengan model pelatihan kepemipinan yang didasarkan pada Peraturan Pemerintah Republik Indonesia No. 14 Tahun 1994 tentang Pendidikan dan Pelatihan Jabatan Pegawai Negeri Sipil. Pelatihan kepemimpinan berdasarkan peraturan tersebut meliputi Pendidikan dan Pelatihan (Diklat) Administrasi Umum (ADUM), Diklat Staf dan PimpinanTingkat Pertama (SPAMA), Diklat Staf dan Pimpinan Tingkat Menengah (SPAMEN), dan Diklat Staf dan Pimpinan Tingkat Tinggi (SPATI). Pelatihan berdasarkan PP No.14 tahun 1994 tersebut hanya berlangsung sampai pada tahun 2001.

Perubahan nomenklatur pelatihan kepemimpinan ketiga terjadi bersamaan dikeluarkannya Keputusan Kepala LAN No. 193 Tahun 2001 tentang Pedoman Umum Pendidikan dan Pelatihan Jabatan PNS. Keputusan tersebut menyebutkan bahwa jenjang pelatihan kepemimpinan terdiri dari Pendidikan dan Pelatihan Kepemimpinan (Diklatpim) Tingkat IV, Diklatpim Tingkat III, Diklatpim Tingkat II, Diklatpim Tingkat II dan DIklatpim Tingkat I. Pada tahun 2013, LAN RI menerapkan diklatpim pola baru menggantikan diklatpim pola lama yang dianggap tidak efektif (Budiati, 2012). Penyelenggaraan pola lama dianggap sudah tidak sesuai lagi karena terdapat banyak kelemahan sehingga dibutuhkan sebuah pembaharuan (Abdullah, 2018). Perubahan tersebut didasarkan pada Peraturan Kepala LAN No.10 Tahun 2013,
No.11 tahun 2013, No.12 Tahun 2013, No.13 Tahun 2013 masing-masing tentang Pedoman Penyenggaraan Pendidikan dan Pelatihan Kepemimpinan Tingkat I, II, III dan IV. Perubahan ini dimaknai sebagai suatu inovasi utamanya mencakup pada penekanan aspek belajar secara langsung dari pengalaman peserta pada saat merancang dan mengerjakan proyek perubahan (Budiati, 2015). Pada dasarnya perbedaan model pelatihan kepemimpinan secara umum pada diklatpim pola baru yaitu adanya proyek perubahan.

Adanya agenda reformasi birokrasi menuntut perubahan model pelatihan kepemimpinan, sehingga pelatihan kepemimpinan kembali mengalami perubahan. Perubahan tersebut terjadi akibat adanya penghapusan eselon III dan IV yang akan mulai berlaku pada Bulan Juni 2020. Masing-masing jabatan strutkrul eselon IV dan III berganti nama sebagai jabatan pengawas dan adminstrator. Perubahan tersebut juga melibatkan perubahan nomenklatur dari pendidikan dan pelatihan kepemimpinan (diklatpim) menjadi pelatihan kepemimpinan. Perubahan pelatihan kepemimpinan antara lain sebagai berikut: 1) Diklatpim IV berubah menjadi Pelatihan Kepemimpinan Pengawas (PKP) yang didasarkan pada peraturan LAN No. 15 Tahun 2019 tentang PKP; 2) Diklatpim Tingkat III berubah menjadi Pelatihan Kepemimpinan Administrator (PKA) yang didasarkan pada Peraturan LAN No 16 Tahun 2019 tentang PKA; 3) Diklatpim Tingkat II berubah menjadi Pelatihan Kepemimpinan Nasional Tingkat II berdasarkan Peraturan LAN No. 2 Tahun 2019 tentang Pelatihan 
Kepemimpinan Nasional Tingkat II; serta 4)

Diklatpim Tingkat I berubah menjadi

Pelatihan Kepemimpinan Nasional Tingkat I berdasarkan Peraturan LAN No.16 Tahun 2018 tentang Pelatihan Kepemimpinan Nasional Tingkat I.

\section{EFEKTIVITAS PELATIHAN KEPEMIMPINAN}

$\begin{array}{ccr}\text { Pada } & \text { dasarnya } & \text { pelatihan } \\ \text { kepemimpinan } & \text { bertujuan } & \text { untuk } \\ \text { meningkatkan } & \text { kinerja individu dan }\end{array}$ organisasi. Alumni diharapkan mampu menunjukkan peningkatan kinerja dengan mengimplementasikan pengetahuan yang didapat selama pelatihan dan disesuaikan dengan kondisi lembaga alumni. Selanjutnya, diperlukan evaluasi yang komprehensif dan berkelanjutan terhadap pelatihan kepemimpinan untuk memastikan apakah tujuan yang diharapkan dalam penyelenggaraan pelatihan telah tercapai.

Efektif atau tidaknya program pelatihan kepemimpinan seharusnya dapat menjadi bahan evaluasi bagi pelaku kebijakan dan penyelenggara pelatihan (Abdullah, 2018). Kirchner \& Akdere, (2014) menambahkan bahwa tanpa adanya metode evaluasi yang efektif atau pemahaman yang komprehensif, dan sama terhadap pengembangan kepemimpinan ini, maka organsasi yang terlibat dalam upaya pelatihan ini akan terus berinvestasi dalam hal yang tidak pernah diketahuinya. Evaluasi pelatihan kepemimpinan bertujuan untuk menentukan tingkat efektivitas suatu program pelatihan, bukan hanya membandingkan antara kemampuan peserta sebelum dan sesudah pelatihan (pre dan post test). Evaluasi diharapkan dapat menjadi dasar bagi pihak-pihak yang bertanggung jawab dalam program tersebut untuk membuat keputusan (Kirkpatrick, 2008). Berdasarkan Kirkpatrick (1959), ketika melakukan evaluasi efektivitas suatu pelatihan, outcome dari pelatihan tersebut dapat dikategorikan kedalam salah satu dari empat kriteria: reactions, learning, behavior dan result level. Evaluasi pelatihan kepemimpinan dari berbagai literatur.

\subsection{Reaction Level}

Reaksi merefleksikan tingkat kepuasan peserta terhadap penyelenggaraan pelatihan. Beberapa indikator terkait kedalam evaluasi tingkat reaksi antara lain penguasaan dan penyampaian materi pelatih, kesesuaian manfaat materi, metode pelatihan serta sarana dan prasarana. Secara umum evaluasi level reaksi didasarkan pada beberapa literatur yang dirangkum pada Tabel 1.

Tabel 1 menunjukkan bahwa masih diperlukan perbaikan pada beberapa aspek yang dievalusi. Pada aspek widyaiswara, diperlukan peningkatan kompetensi widyaiswara dalam menyampaikan materi khususnya akibat adanya tuntutan perubahan pola pelatihan kepemimpinan yang dinamis. Selain itu, adanya hambatan dari faktor internal widyaiswara seperti adopsi ilmu pengetahuan maupun teknologi baru menjadi faktor penghambat tercapainya pelatihan kepemimpinan. Budiati (2015) menunjukkan pada populasi widyaiswara di semua Badan Diklat di Indonesia, selalu terdapat $16 \%$ kelompok adopter inovasi konservatif. Mereka adalah orang-orang yang berpandangan skeptis terhadap setiap perubahan atau inovasi 
yang selalu menimbulkan ketidakpastian yang memaksa harus mempelajari hal-hal baru. Kondisi tersebut timbul akibat adanya perubahan pelatihan kepemimpinan pola baru.

Pada aspek metode pelatihan, metode yang digunakan relatif kurang efektif. Hal ini diakibatkan metode yang digunakan terbatas pada beberapa metode saja. Handayani et al., (2015) menambahkan bahwa secara umum pelatihan kepemimpinan dilakukan di dalam kelas. Diperlukan penganekaragaman metode yang digunakan dalam rangka meningkatkan retensi pengetahuan, sikap dan perilaku peserta pelatihan (Lacerenza et al., 2017). Penggunaan metode yang beragam akan memiliki dampak terhadap peningkatan learning, behavior dan results secara sekaligus (Abner et al., 2019).

Sejalan dengan aspek metode, aspek materi harus dilakukan penyelarasan terhadap tujuan organisasi. Abdullah (2018) menyatakan bahwa adanya keunikan pada masing-masing organisasi baik dari segi tujuan maupun kebutuhan kompetensi kepemimpinan maka pelatihan kepemimpinan seharusnya dapat menyesuaikan terhadap kondisi organisasi tersebut. Faktanya, kompetensi kepemimpinan yang dibangun dalam pelatihan kepemimpinan saat ini masih bersifat generik (umum).

Tabel 1. Evaluasi tingkat Reactions dari beberapa literatur

\begin{tabular}{|c|c|c|c|c|}
\hline \multirow{2}{*}{ Penulis } & \multicolumn{4}{|c|}{ Aspek yang di evaluasi } \\
\hline & Materi & Widyaiswara & Metode & Sapras \\
\hline $\begin{array}{l}\text { (Handayani et } \\
\text { al., 2015) }\end{array}$ & $\begin{array}{ll}\text { Telah } & \text { sesuai } \\
\text { dengan } & \text { bidang } \\
\text { tugas peserta } & \end{array}$ & $\begin{array}{l}\text { Penguasaan dan } \\
\text { penyampaian relatif } \\
\text { sudah baik }\end{array}$ & $\begin{array}{lr}\text { Kurang } & \text { efektif } \\
\text { karena } & \text { terlalu } \\
\text { banyak di ruangan } \\
\text { kelas }\end{array}$ & $\begin{array}{lr}\text { Fasilitas } & \text { yang } \\
\text { diberikan } & \text { selama } \\
\text { diklat } & \text { relatif } \\
\text { kurang lengkap }\end{array}$ \\
\hline $\begin{array}{l}\text { (Wulandari, } \\
\text { 2012) }\end{array}$ & $\begin{array}{l}\text { Terdapat } \\
\text { kesesuaian materi } \\
\text { dengan pekerjaan }\end{array}$ & $\begin{array}{l}\text { Widyaiswara telah } \\
\text { mampu } \\
\text { berkomunikasi } \\
\text { dengan baik dan } \\
\text { menguasai konsep } \\
\text { kunci }\end{array}$ & $\begin{array}{l}\text { Relatif } \quad \text { cukup } \\
\text { efektif terkait } \\
\text { membangun } \\
\text { interaksi } \\
\text { pembelajaran }\end{array}$ & $\begin{array}{l}\text { Diperlukan } \\
\text { peningkatan } \\
\text { sarana dan } \\
\text { prasarana }\end{array}$ \\
\hline $\begin{array}{l}\text { (Nurseha, } \\
\text { 2013) }\end{array}$ & & $\begin{array}{ll}\text { Secara } & \text { umum } \\
\text { kemampuan } & \\
\text { widyaiswara } & \text { cukup } \\
\text { baik } & \\
\end{array}$ & & $\begin{array}{lr}\text { Sarana } & \text { dan } \\
\text { prasarana perlu } \\
\text { lebih ditingkatkan } \\
\text { lagi }\end{array}$ \\
\hline (Budiati, 2015) & & $\begin{array}{l}\text { Widyaiswara relatif } \\
\text { memiliki tingkat } \\
\text { difusi dan adopsi } \\
\text { inovasi yang rendah } \\
\text { dalam penerapan } \\
\text { perubahan inovasi }\end{array}$ & & \\
\hline $\begin{array}{l}\text { (Rusmulyani, } \\
\text { 2015) }\end{array}$ & $\begin{array}{lr}\text { Materi } & \text { secara } \\
\text { umum telah relevan } \\
\text { dengan } & \text { tuntutan } \\
\text { pekerjaan } & \\
\end{array}$ & $\begin{array}{l}\text { Widyaiswara telah } \\
\text { mampu memahami } \\
\text { prinsip psikologi } \\
\text { pendidikan }\end{array}$ & & \\
\hline $\begin{array}{l}\text { (Sudradjat, } \\
\text { 2010) }\end{array}$ & $\begin{array}{l}\text { Materi terlalu luas } \\
\text { dana bersifat } \\
\text { sangat umum }\end{array}$ & $\begin{array}{ll}\text { Kurangnya } & \\
\text { kemampuan } & \\
\text { widyaiswara } & \text { dalam } \\
\text { menciptakan } & \\
\text { suasana } & \text { yang } \\
\text { mendorong } & \\
\text { pembelajaran } & \end{array}$ & & $\begin{array}{lr}\text { Sarana } & \text { dan } \\
\text { prasarana } & \text { kurang } \\
\text { memadai } & \end{array}$ \\
\hline
\end{tabular}




\subsection{Learning Level}

Evaluasi level pembelajaran merupakan tingkatan evaluasi dalam rangka mengukur kompetensi peserta sesuai dengan tujuan program pelatihan. Evaluasi jenis ini secara umum telah dilaksanakan oleh lembaga pelatihan baik dalam bentuk ujian tertulis, presentasi (on class) maupun evaluasi off class. Akan tetapi penilaian tersebut relatif tidak secara detail menilai terkait skill kepemimpinan yang telah didapatkan oleh peserta antara lain sepert: 1) Apakah pelatihan mampu mengotimalkan keterampilan peserta, 2) Apakah pelatihan mampu menambah kemampuan dalam berkomunkasi, 3) Apakah pelatihan menambah kompetensi kepemimpinan, 4) Apakah pelatihan dapat menambah kemampuan dalam melaksanakan delegasi/wewenang. Berbagai pertanyaan tersebut seharusnya sudah dapat dijawab oleh penyelenggara pelatihan. Akan tetapi, secara keseluruhan dapat disimpulkan bahwa keberhasilan pembelajaran peserta pelatihan hanya dapat dilihat dari nilai hasil ujian peserta dan dibuktikan dengan didapatkannya sertifikat kelulusan (Nurseha, 2013). Lebih ironisnya lagi, terdapat anggapan bahwa pelatihan kepemimpinan umumnya hanya sebagai formalitas, dikarenakan peserta pelatihan kepemimpinan umumnya sudah menduduki jabatan struktural sebelum mereka mengikuti pelatihan tersebut (Amalo, 2017).

\subsection{Behavior Level}

Pada level ini, evaluasi dilakukan untuk mengetahui seberapa jauh sikap dan perilaku para peserta berkembang setelah menerima pelatihan. Dengan kata lain, sejauh mana alumni pelatihan mengaplikasikan informasi dan materi yang telah mereka dapatkan selama mengikuti pelatihan.

Implementasi informasi dan materi yang dicerminkan dari perubahan perilaku alumni sangat beragam salah satunya tergantung pada daya tangkap peserta pelatihan terhadap materi tersebut. Beragamnya implementasi tersebut dikarenakan latar belakang pendidikan dari peserta pelatihan kepemimpinan yang bervariasi. Latar belakang peserta dalam satu angkatan saja dapat bervariasi, mulai dari lulusan sarjana hingga doktoral. Hal ini disebabkan tidak adanya persyaratan terkait dengan latar belakang pendidikan untuk mengikuti pelatihan kepemimpinan. Beberapa persyaratan untuk mengikuti pelatihan kepemimpinan antara lain: 1) Memiliki potensi untuk dikembangkan yang dibuktikan dengan dokumen yang sesuai; 2) Telah memiliki kompetensi teknis sesuai dengan bidang jabatan struktural yang akan diduduki, dibuktikan dengan dokumen yang sesuai; 3) Ketentuan pangkat; 4) Mampu berkomunikasi dengan bahasa inggris yang dibuktikan dengan sertifikat; serta 5) surat rekomendasi (Hudalil, 2014).

Hasil penelitian Nurseha (2013) dan Wulandari (2012) menunjukkan bahwa secara umum pelatihan kepemimpinan telah mampu menghadirkan perubahan perilaku dari sisi prestasi pegawai, tanggung jawab, dan kedisiplinan. Akan tetapi, masih juga terdapat hal yang perlu dilakukan perbaikan. Tidak dapat dipungkiri bahwa masih terdapat kecenderungan alumni pelatihan kepemimpinan untuk kembali ke perilaku sebelum mengikuti 
pelatihan. Wardani \& Suryono (2014) menyatakan bahwa peserta sudah tidak lagi merasakan semangat kerja yang tinggi dan kedisiplinan tepatnya setelah 1 tahun alumni pelatihan kembali pada instansinya masing-masing. Dengan kata lain, perubahan perilaku peserta hanya terjadi dalam jangka pendek. Oleh karena itu, diperlukan dukungan, pembinaan dan pengawasan secara kontinu terhadap alumni pelatihan kepemimpinan setelah pelatihan selesai (Sujarwo, 2008)

\subsection{Result Level}

Berdasarkan

Kirkpatrick

(1959), tingkatan hasil merupakan metode evaluasi yang merefleksikan dampak dari program pelatihan terhadap ketercapaian tujuan organisasi. Results juga sering didefinisikan dalam hal seberapa besar manfaat pelatihan yang diperoleh dibandingkan dengan biaya pelaksanaan program pelatihan atau Return on Investment (Arthur et al., 2003). Dari kedua pengertian tersebut, dapat disimpulkan bahwa evaluasi level results digunakan dalam rangka ingin mengetahui seberapa besar dampak pelatihan kepemimpinan terhadap kinerja organisasi.

Pada dasarnya evaluasi dampak pelatihan kepemimpinan telah diatur dalam Peraturan Lembaga Administrasi Negara yang dikenal sebagai evaluasi pasca pelatihan. Evaluasi pasca pelatihan umumnya dilakukan antara 6 sampai 12 bulan setelah penyelenggaraan pelatihan dilaksanakan. Evaluasi pasca pelatihan dilakukan untuk mengukur tingkat pemanfaatan alumni, peningkatan kinerja alumni dan kinerja organisasi.
Hasil dari evaluasi pasca pelatihan menunjukkan bahwa diperlukan peningkatan khususnya dalam 3 aspek tersebut. Yunita et al., (2017) menunjukkan bahwa pemanfaatan alumni pelatihan kepemimpinan relatif rendah. Hasil ini didapatkan dari 95 alumni yang dijadikan responden oleh PKP2A LAN, hanya terdapat 1 alumni yang sudah dipromosikan jabatannya ke tingkat yang lebih tinggi. Sekitar 49 dan 41 alumni masing masing masih pada jabatan yang sama dan dimutasi ke jabatan setingkat namun berbeda instansi, sementara 4 alumni sisanya tidak menduduki jabatan sama sekali atau non job. Jumlah alumni yang relatif besar yaitu 90 orang tidak merepresentasikan tingginya tingkat pemanfaatan lulusan pelatihan. Hal ini dikarenakan keikutsertaan alumni pada pelatihan kepemimpinan adalah dalam konteks hanya memenuhi syarat sebagai pegawai yang sudah menduduki jabatan struktural yang sedang diembannya.

Terdapat beberapa alasan terkait minimnya pemanfaatan alumni pelatihan kepemimpinan. Pertama, belum optimalnya pemanfaatan alumni akibat kelulusan seseorang pada pelatihan kepemimpinan belum menjadi dasar pertimbangan pengembangan karir (promosi) pegawai. Kedua, tidak adanya jaminan bagi alumni pelatihan untuk pengembangan karirnya kedepan.

Kondisi yang serupa terjadi pada aspek peningkatan kinerja alumni dan organisasi. Yunita et al. (2017) menunjukkan bahwa lebih dari 27\% tidak mengalami adanya peningkatan kinerja (akuntabilitas dan kualitas pelayanan) 
setelah mengikuti pelatihan. Hasil ini sejalan dengan Burke \& Hutchins, (2007) yang menunjukkan bahwa $40 \%$ alumni pelatihan tidak segera mengimlementasikan hasil pelatihan setelah kembali bekerja, $70 \%$ gagal dalam mengimplementasikan pelatihan 1 tahun setelah mengikuti program pelatihan dan pada akhirnyam hanya $50 \%$ dari investasi untuk pelatihan berdampak dalam perbaikan kinerja individu, tim, dan organisasi.

\section{PENGEMBANGAN SISTEM PELATIHAN KEPEMIMPINAN}

Dalam mempersiapkan pemimpin yang diharapkan dapat menjaga keberlanjutan organisasi pemerintah, diperlukan pembenahan system pelatihan kepemimpinan yang selama ini sudah diterapkan. Pembenahan tersebut diimplementasikan melalui kebijakan, yaitu:

\section{(1) Reorentasi system pendidikan dan} pelatihan melalui perubahan peraturan. Ketidakpastian global dalam semua tataran kehidupan seperti saat ini dan agenda perubahan birokrasi yang ditandai dengan diterbitkannya Surat Edaran (SE) 393/2019 tentang langkah strategis dan konkret penyederhanaan birokrasi menimbulkan perubahan signifikan dalam struktur kepemimpinan organisasi pemerintah. Kondisi tersebut menuntut lembaga pelatihan untuk dapat menghasilkan suatu inovasi dalam meningkatkan efektivitas program pelatihan kepemimpinan. Dalam rangka memenuhi tuntutan tersebut diperlukan suatu reorientasi peraturan terkait pelatihan kepemimpinan. Pengembangan inovasi system pelatihan sudah saatnya diserahkan pada masingmasing institusi seperti kementerian dan pemerintah daerah. Penyerahan tersebut hanya ditekankan pada penentuan kurikulum terkait instansi masing-masing. Hal ini dilatarbelakangi adanya fakta bahwa masing-masing institusi membutuhkan pemimpin dengan spesifikasi tertentu yang unik dan hanya institusi tersebut yang secara pasti mengetahui kebutuhan pemimpin untuk menjalankan organisasinya. Sementara, LAN tetap menjadi penjamin mutu terhadap pelatihan kepemimpinan yang dijalankan.

Transformasi kemampuan fasilitator. Adanya agenda restrukturisasi jenjang kepemimpinan menuntut lembaga pelatihan untuk segera melakukan transformasi kemampuan widyaiswara. Saat ini, widyaiswara dituntut untuk selalu menyesuaikan diri terhadap perkembangan baik pengetahuan maupun metodologi terkait bagaimana menumbuhkan dan mengembangkan jiwa kepemimpinan calon pemimpin masa depan. Di sisi lain, lembaga pelatihan juga harus memastikan widyaiswara merupakan seseorang yang benar-benar kompeten dalam spesialisasi ilmu kepemimpinan tertentu. Hal tersebut dapat dipenuhi dengan menetapkan standar kualitas dan kuantitas, perekrutan dengan system merit dan sertifikasi kompetensi. Sertifikasi kompetensi diharapkan dapat mencerminkan spesialisasi dari widyaiswara pada materi tertentu. Selain itu, fasilitator eksisting terus dilakukan peningkatan kompetensinya baik melalui pelatihan, kursus maupun pemagangan. Kebijakan tersebut harus menjadi prioritas sehingga nantinya dapat 
menjadi pioneer percontohan bagi pengembangan model lembaga pelatihan kepemimpinan.

Namun, kebijakan tersebut nantinya tidak akan terlaksana secara optimal apabila tidak ditunjang oleh strategi dari lembaga pelatihan itu sendiri. Oleh karena itu, diperlukan strategi dalam melakukan implementasinya. Strategi implementasi akan dilakukan dengan menggunakan pendekatan input, proses dan output.

\subsection{Manajemen Talenta Sebagai Dasar} Pertimbangan Input Pelatihan Kepemimpinan

Pengembangan pemimpin masa depan untuk kebutuhan suatu organisasi merupakan hal yang mutlak saat ini. Pemimpin masa depan harus mempunyai karakter, kompetensi dan literacy. Karakter adalah usaha yang disengaja, bersifat proaktif, dan dilakukan lembaga dan pemerintah untuk menanamkan nilai-nilai inti dalam etika, seperti kepedulian, kejujuran, keadilan, tanggung jawab, serta penghargaan terhadap orang lain, (Komara, 2018). Kompetensi merupakan kemampuan atau kecakapan yang dimiliki oleh seseorang dalam melaksanakan suatu pekerjaan atau tugas di bidang tertentu, sesuai dengan jabatan yang disandangnya.

Dengan kata lain, kompetensi tidak hanya tentang pengetahuan atau kemampuan seseorang, yang tercermin dari kemampuan berfikir dan bertindak secara konsisten, tetapi juga kemauan melakukan apa yang diketahui sehingga menghasilkan manfaat.

Sementara itu literacy dibutuhkan bagi pemimpin masa depan, karena literasi bukan hanya kemampuan seseorang dalam mengolah dan memahami, melibati, menggunakan, menganalisis, dan mentransformasikan informasi saat melakukan proses membaca dan menulis, tetapi juga kemampuan yang harus dimiliki oleh seorang calon pemimpin untuk mengenali dan memahami ide-ide yang disampaikan secara visual. Literasi mencakup pengetahuan seseorang berkomunikasi di segala lini kehidupan dalam masyarakat, yang sangat diperlukan oleh seorang pemimpin masa depan yang hidup di zaman yang diwarnai kecanggihan teknologi saat ini. Karena kemampuan literasi ini bisa menjadi kunci untuk berproses menjadi pemimpin yang lebih berpengetahuan dan berperadaban.

Bertolak dari berbagai tujuan tersebut, diperlukan suatu konsep baru dalam rangka menghasilkan calon pemimpin masa depan. Salah satu mekanisme yang dapat ditempuh adalah melalui manajemen talenta. Manajemen talenta dipandang sebagai implementasi strategi atau sistem yang terintegrasi, yang dirancang untuk meningkatkan kinerja melalui proses menarik dan menyeleksi, mengembangkan, memanfaatkan serta mempertahankan pegawai yang memiliki keahlian dan bakat (talent) dalam rangka memenuhi kebutuhan organisasi saat ini dan masa datang (Lockwood, 2006).

Melalui manajemen talenta diharapkan akan meningkatkan trust organisasi dan para stakeholders, sehingga nantinya dapat meningkatkan kinerja organisasi secara keseluruhan. Manajemen talenta sendiri didasarkan pada PP No. 11 tahun 2017 tentang Manajemen PNS melalui penelusuran dan pengembangan ASN 
potensial melalui berbagai assesmen dan pembimbingan berkelanjutan. Manajemen talenta dimaksudkan agar pegawai yang berkinerja unggul dapat dipertahankan dan dipromosikan ke dalam suatu jabatan structural tertentu.

Tahapan pengembangan manajemen talenta terdiri dari: 1) Analisis kebutuhan talenta, pada tahapan ini akan dilakukan identifikasi jabatan organisasi setiap tahunnya sehingga dapat menggambarkan kebutuhan jabatan organisasi yang harus di isi secara berkala; 2) Identifikasi calon talenta, dimana terdiri dari pemetaan jabatan melalui penelusuran minat dan bakat terkait karakter dan kompetensi kepemimpinan baik melalui assesmen psikologis maupun wawancara. Selain assesmen minat dan bakat, tahapan ini juga akan dilakukan seleksi rekam jejak/ integritas dan administrasi; 3) Pengembangan talent, tahapan ini meliputi pendampingan bagi talent oleh mentor yang ditetapkan oleh institusi. Dengan bantuan coach, diharapkan pegawai bertalenta dapat menemukan peluang baru dalam diri mereka dan belum dapat ditemukan sendiri sebelumnya (Krissetyanti, 2013). Proses mentoring tidak harus bersifat formal, yang lebih diutamakan adalah kedisiplinan mentor dan talenta untuk melaksanakan peran mereka masing-masing dalam proses mentoring. Proses mentoring tersebut dimaksudkkan untuk mengimplementasikan individual development project. 4) Evaluasi talent, tahapan ini terdiri diri kegiatan assesmen talent berdasarkan unsur kelayakan dan kepatutan. Pada tahapan ini juga akan dilakukan monitoring dan evaluasi. Hasil akhir dari tahapan ini adalah menghasilkan calon pemimpin yang nantinya siap mengikuti pelatihan kepemimpinan.

\subsection{Restrukturisasi Sistem Pelatihan Kepemimpinan sebagai pendekatan proses}

Adanya evolusi yang ditandai kearah personal-learning melalui kemudahan teknologi diperkirakan akan memiliki dampak dramatis pada pengembangan pemimpin masa depan. Oleh karena itu, diperlukan restrukturisasi system pelatihan kepemimpinan yang awalnya terkesan rigid dan kaku menjadi suatu pelatihan kepemimpinan yang fleksibel. Restrukturisasi diawali dengan perubahan paradigma melalui penyediaan pelatihan kepemimpinan berdasarkan dua system yaitu voluntary dan mandatory serta kompetitif. Kedua system didasarkan pada 5 tingkatan kerangka pengembangan kepemimpinan yang bersifat ordinal berdasarkan level kepemimpinan. Kerangka tersebut dari yang terendah hingga paling tinggi, yaitu; 1)managing self, 2) managing project, 3)Leading \& Managing People, 4)Leading \& Managing Programs dan 5)Leading and Managing Organization. Sistem pelatihan yang bersifat mandatory dan volunatry hanya pada tingkatan managing yourself, sementara tingkatan kompetensi yang lain diperuntukkan bagi calon pemimpin berdasarkan level kepemimpinannya. Pada tingkatan managing yourself, pelatihan yang akan disediakan berupa pelatihan berbasis microlearning dalam berbagai konten dari semua eselon I melalui platform Cross Agency Training Program. Program ini didisain untuk memastikan bahwa 
karyawan mendapatkan informasi yang tepat waktu dan berguna terkait dengan berbagai isu strategis pada masing-masing eselon I-nya. Pengkayaan materi dapat diakses melalui microlearning berdurasi 810 jam dalam durasi selama 2 minggu. Platform tersebut merupakan website yang menyediakan artikel, video dan buku yang menunjang pengembangan kompetensi calon pemimpin. Calon pemimpin selain diharuskan mengambil program pelatihan pada agensinya, mereka juga dapat memperkaya kompetensinya dengan mengambil program dari agensi lain yang bersifat voluntary (cross agency). Oleh karena itu, calon pemimpin tersebut nantinya dapat memiliki kompetensi yang bersifat mandatory dan voluntary. Program pelatihan tersebut sebagai syarat cukup bagi calon pemimpin untuk mengikuti program pelatihan kepemimpinan tingkat selanjutnya.

Pada level kepemimpinan 2-5 sistem kompetitif diterapkan sejak calon pemimpin tersebut masuk kedalam manajemen talenta, dimana masing-masing calon tersebut harus berkompetensi untuk dapat mengikuti program pelatihan kepemimpinan. Pelatihan ini dirancang berdurasi selama setahun dengan metodologi yang meminimalkan on class training, melainkan off class training melalui penerapan proyek perubahan di tempat kerja. Selama proses pelatihan, peserta akan dilibatkan pada kurikulum interaktif melalui berbagai aktivitas dan penugasan yang terdiri dari self-learning activities via microlearning, tatap muka, visitasi, building mentoring relationship, pengembangan proyek perubahan, shadowing assignments, presentasi, interview dan implementasi proyek perubahan. Secara lebih detail, program ini akan melibatkan 3 fase utama. Fase pertama ditunjukan untuk peserta mendapatkan personal insight dan leadership mastery dengan melibatkan selflearning activities seperti tatap muka di kelas dan microlearning. Fase kedua, peserta diminta untuk merancang proyek perubahan, dimana rancangan tersebut merupakan hasil dari metode building mentoring relationship, interview, shadowing assignments dan visitasi. Pada fase terakhir, peserta tersebut diminta untuk menerapkan rancangannya tentunya dengan proses mentoring dari seorang mentor.

Berbagai metodologi yang ditawarkan tersebut diharapkan dapat membuat peserta merasa lebih terikat dan memiliki terhadap organisasi yang akan dipimpinya. Selain itu, peserta juga menyelesaikan penilaian 360 derajat yang diberikan sebelum dan 12 bulan sesudah program pelatihan selesai. Penilaian 360 derajat bertujuan memastikan penilaian kompetensi kepemimpinan peserta pada setiap sisi (pimpinan, staff, sesama, internal dan eksternal pengguna layanan) dalam rangka mendapatkan gambaran yang menyeluruh terhadap potensi kepemimpinan seseorang. Pada level kepemimpinan $\quad 3-5, \quad$ calon pimpinan/pimpinan akan diminta untuk menyelesaikan proyek perubahan setiap tahunnya, tidak hanya disaat mereka mendapatkan promosi. Dengan demikian, tidak ada pimpinan yang underdeveloped, tidak terkecuali seberapa lama mereka telah menduduki suatu jabatan pimpinan. 
Adanya penilaian tersebut digunakan tidak hanya untuk mengukur peserta, tetapi juga untuk perbaikan program pelatihan kepemimpinan kedepan. Peserta yang telah menyelesaikan program ini tidak secara langsung dijamin dapat mendapatkan jabatan tertentu, namun pastinya posisi jabatan tersebut hanya dapat di isi oleh calon pemimpin yang telah lulus program ini.

\subsection{Mencetak Pemimpin Handal melalui}

\section{Buying Leaders}

Program ini menawarkan pendekatan unik dimana didisain untuk menarik lulusan master atau doktor dari luar organisasi yang nantinya akan mengikuti program pelatihan kepemimpinan. Program ini dikhususkan pada lulusan dari universitas bereputasi dan memiliki outstanding achievement selama masa kuliah, dimana nantinya akan mengikuti program pelatihan selama satu-dua tahun. Kandidat akan diseleksi melalui proses seleksi yang kompetitif dengan melibatkan ahli. Peserta yang mengikuti program akan dilibatkan pada berbagai aspek organisasi melalui penugasan rotasional dalam lingkup organisasinya. Tentunya sebelum melaksanakan penugasan tersebut para peserta akan mendapatkan pembekalan secara materi baik secara offline maupun online. Monitoring dan evaluasi akan dilakukan secara berkala selama program berlangsung. Masing-masing peserta mendapatkan mentoring dari pemimpin baik dari organisasi itu sendiri maupun dari luar, dimana pemilihan mentor akan diakomodasi melalui platform mentor pool. Setelah menyelesaikan program, peserta akan diarahkan kepada alur karir terntentu.

\subsection{Integrasi Program Pelatihan} Kepemimpinan dengan Lelang Jabatan melalui Pemanfaatan Talent Pool

Calon pemimpin yang telah melalui program pelatihan menjadi SDM siap pakai untuk menduduki jabatan tertentu. Kertebatasan jabatan yang harus di isi memungkinkan lembaga pelatihan untuk membuat talent pool platform. Platform tersebut berfungsi sebagai database calon pemimpin berkualitas. Database tersebut merupakan data calon pemimpin yang telah lulus program pendidikan dan pelatihan tetapi belum terdapat jabatan yang bisa diduduki. Sementara itu, lelang jabatan yang diadakan oleh organisasi diharuskan hanya melibatkan calon pemimpin yang telah melalui program pendidikan dan pelatihan kepemimpinan. Adanya integrasi tersebut meningkatkan akuntabilitas dan transparansi proses pengisian jabatan pemimpin dari suatu organisasi. Selain itu, talent pool platform juga memastikan bahwa tidak akan terjadi kekosongan pemimpin organisasi yang terlalu lama. Hal ini dikarenakan dengan adanya database tersebut, organisasi dapat langsung mengikutsertakan calon pemimpin tersebut dalam mekanisme lelang jabatan dalam waktu yang relative singkat. Dengan begitu, proses menjadi pemimpin dari suatu organisasi tersebut dapat berjalan kompetitif, efektif, efisien dan terukur.

\section{PENUTUP}

Pelatihan kepemimpinan harus menghasilkan pemimpin yang handal, yang mempunyai karakter, kompetensi dan literacy, sehingga nantinya dapat 
meningkatkan produktivitas organisasi yang dipimpinnya. Oleh sebab itu, lembaga pendidikan dan pelatihan kepemimpinan dapat mengembangkan kerangka strategi pendekatan secara holistik: Pendekatan input, pengembangan calon peserta program pendidikan dan pelatihan melalui manajemen talenta, dikembangkan dalam rangka memastikan bahwa calon peserta yang akan mengikuti program pendidikan dan pelatihan kepemimpinan merupakan orang pilihan yang telah melalui seleksi talenta sebelumnya pada masing-masing agensi. $\mathrm{Hal}$ ini dilakukan dalam rangka meminimalkan resiko rendahnya motivasi calon peserta program dan juga efektif dan efisien dalam penggunaan anggaran. Dengan kata lain, melalui manajemen talenta karyawan akan dipetakan dan dibimbing dalam rangka menghasilkan pemimpin masa depan.

\section{Restrukturisasi program pelatihan} melalui inovasi model program, pengembangan lembaga dan buying leaders, diperlukan restrukturisasi metodologi pelatihan fleksibel dengan menekankan pada metode off training. Sementara itu, dalam rangka memenuhi kebutuhan pemimpin yang actual maka tidak hanya dapat dipenuhi dengan pengembangan karyawan saja namun diperlukan pengembangan rekrutmen pemimpin melalui buying leaders.

Integrasi program pendidikan dan pelatihan dengan lelang jabatan memungkinkan lembaga pelatihan untuk membuat talent pool platform. Platform tersebut berfungsi sebagai database calon pemimpin berkualitas. Database merupakan data calon pemimpin yang telah lulus program pendidikan dan pelatihan tetapi belum terdapat jabatan yang bisa diduduki. Sementara itu, lelang jabatan yang diadakan oleh organisasi diharuskan hanya melibatkan calon pemimpin yang telah melalui program pendidikan dan pelatihan kepemimpinan. Adanya integrasi tersebut meningkatkan akuntabilitas dan transparansi proses pengisian jabatan pemimpin dari suatu organisasi.

\section{DAFTAR PUSTAKA}

Abdullah, M. (2018). Pola Pengembangan Kompetensi Kepemimpinan Bagi Aparatur Pemerintah dalam Menghadapi Tantangan Global (Studi Kasus Pada Penyelenggaraan Diklat Kepemimpinan Tingkat IV Di KESDM). Jurnal Wacana Kinerja: Kajian Praktis-Akademis Kinerja Dan Administrasi Pelayanan Publik, 21(1), 19-48.

https://doi.org/10.31845/jwk.v21i1.63

Abner, G., Morrison, J., Perry, J., \& Valdez, B. (2019). Preparing the Next Generation of Federal Leaders: Agency-Based Leadership Development Programs. IBM Center for the Business of Goverment. http://www.businessofgovernment.org/ report/preparing-next-generationfederal-leaders-agency-basedleadership-development-programs

Amalo, C. V. (2017). Efektivitas sistem pendidikan dan pelatihan struktural di pemerintah kota kupang. Jurnal Inovasi Kebijakan, 2(1), 19-39. https://jurnalinovkebijakan.com/index. php/JIK/article/view/7

Amaluis, D. (2014). Analisis Efektifitas Program pelatihan Diklat Pim lii Terhadap Kompetensi Pejabat Eselon lii Di Pemerintah Kabupaten. Journal of Economic and Economic Education, 3(1), 18-26.

Arthur, W., Bennett, W., Edens, P. S., \& Bell, S. T. (2003). Effectiveness of training in organizations: A metaanalysis of design and evaluation features. Journal of Applied Psychology, 88(2), 234-245. 
https://doi.org/10.1037/00219010.88.2.234

Budiati, L. (2012). Good Governance Dalam Pengelolaan Lingkungan Hidup. Bogor: Penerbit Ghalia Indonesia.

Budiati, L. (2015). Diklat Kepemimpinan Pola Baru Dalam Perspektif Inovasi dan Pembelajaran Konstruktivistik. Jurnal Pembangunan Wilayah \& Kota, 11(2), 211. https://doi.org/10.14710/pwk.v11i2.10 849

Burke, L. A., \& Hutchins, H. M. (2007). Training transfer: An integrative literature review. Human Resource Development Review, 6(3), 263-296. https://doi.org/10.1177/153448430730 3035

Day, D. V. (2000). Leadership development: A review in context. The Leadership Quarterly, 11, 581-613. http://dx.doi.org/10.1016/S1048 9843(00)00061-8

Handayani, W. T., Suryono, A., \& Said, A. (2015). Efektivitas Pelasanaan Pendidikan dan Pelatihan Kepemimpinan Pegawai Negeri Sipil ( Studi di Badan Kepegawaian Daerah Kabupaten Probolinggo ). Jurnal Administrasi Publik, 3(5), 824-828.

Hudalil, A. (2014). Teknis Seleksi Peserta Diklatpim IV Pola Baru di Badan Pendidikan dan Pelatihan Daerah Kabupaten Lampung Tengah. Jurnal Lingkar Widaiswara, Vol.1(2):14-21

Kirchner, M. J., \& Akdere, M. (2014). Leadership Development Programs: an Integrated Review of Literature. Bilgi Ekonomisi ve Yönetimi Dergisi, 9(1), 137-146.

Kirkpatrick, D. (1959). Techniques for evaluating training programs. Journal of the American Society for Training and Development, 13, 3-9.

Kirkpatrick, D.L., \& Kirkpatrick, J.D. (2008). Evaluating Training Programs. San Francisco: Berrett-Koehler Publishers, Inc.

Krissetyanti, E. P. L. (2013). Penerapan Strategi Manajemen Talenta Dalam Pengembangan Pns the. Jurnal Kebijakan Dan Manajemen PNS, 7(1), $1-15$.

Komara, E. (2018). "Penguatan Pendidikan Karakter dan Pembelajaran Abad 21" in SIPATAHOENAN: South-East Asian Journal for Youth, Sports \& Health Education, Volume 4(1), April, pp.17-26. Bandung, Indonesia: Minda Masagi Press owned by ASPENSI, ISSN 2407-7348.

Lacerenza, C. N., Reyes, D. L., Marlow, S. L., \& Joseph, D. L. (2017). Leadership Training Design, Delivery, and Implementation: A Meta-Analysis. Journal of Applied Psychology, 102(12), 1686-1718. https://doi.org/10.1037/apl0000241

Lembaga Administrasi Negara. (2001). Keputusan Kepala LAN tentang Pedoman Umum Pendidikan dan Pelatihan Jabatan PNS (Kep. Kepala LAN No. 193 Tahun 2001). Jakarta: Penulis, Diakses dari: http://ppid.lan.go.id/wpcontent/uploads/2014/08/KeplanNo.193-Tahun-2001-TentangPedoman-Umum-Diklat-JabatanPNS.pdf

Lembaga Administrasi Negara. (2013). Peraturan Kepala Lembaga Administrasi negara tentang Pedoman Penyelenggaraan Pendidikan dan Pelatihan Kepemimpinan Tingkat I (PERKALAN No.10 Tahun 2013). Jakarta: Penulis. Diakses dari: https://bit.ly/3aYQ3v9

Lembaga Administrasi Negara. (2013). Peraturan Kepala Lembaga Administrasi negara tentang Pedoman Penyelenggaraan Pendidikan dan Pelatihan Kepemimpinan Tingkat II (PERKALAN No.11 Tahun 2013). Jakarta: Penulis. Diakses dari: https://bit.ly/2WqwFls

Lembaga Administrasi Negara. (2013). Peraturan Kepala Lembaga Administrasi negara tentang Pedoman Penyelenggaraan Pendidikan dan Pelatihan Kepemimpinan Tingkat III (PERKALAN No.12 Tahun 2013). Jakarta: Penulis. Diakses dari: https://bit.ly/3aZCADs

Lembaga Administrasi Negara. (2013). Peraturan Kepala Lembaga Administrasi negara tentang Pedoman Penyelenggaraan Pendidikan dan Pelatihan Kepemimpinan Tingkat IV (PERKALAN No.13 Tahun 2013). Jakarta: Penulis. Diakses dari: https://bit.ly/2WIINW5

Lembaga Administrasi Negara. (2013). Peraturan Kepala Lembaga Administrasi Negara tentang Standar Biaya Umum Pendidikan dan Pelatihan PNS Tahun 2014 (PERKALAN Nomor 20 Tahun 2013). 
Jakarta: Penulis. Diakses dari: https://diklatpimlan.files.wordpress.co m/2010/02/peraturan-kepala-lannomor-20-tahun-2013.pdf

Lembaga Administrasi Negara. (2018). Peraturan Lembaga Administrasi Negara tentang Rincian Biaya Penyelenggaraan Diklat Kepemimpinan Tingkat I, II, III dan IV (PERLAN Nomor 2 Tahun 2018). Jakarta: Penulis. Diakses dari https://makassar.lan.go.id/wpcontent/uploads/2019/08/PeraturanLAN-Nomor-2-Tahun-2018-ttgRincian-Biaya-PenyelenggaraanDiklat-PIM-Tkt-I-II-III-n-IV-LatsarCPNS-Gol-II-n-III-serta-Latsar-CPNSHonorer.pdf

Lembaga Administrasi Negara. (2018). Peraturan Lembaga Administrasi negara tentang Pelatihan Kepemimpinan Nasional Tingkat I (PERLAN No.6 Tahun 2018). Jakarta: Penulis. Diakses dari: https://bit.ly/2WAw695

Lembaga Administrasi Negara. (2019). Peraturan Lembaga Administrasi negara tentang Pelatihan Kepemimpinan Nasional Tingkat II (PERLAN No.2 Tahun 2019). Jakarta: Penulis. Diakses dari: https://bit.ly/2LOICsJ

Lembaga Administrasi Negara. (2019). Peraturan Lembaga Administrasi negara tentang Pelatihan Kepemimpinan Pengawas (PERLAN No.15 Tahun 2019). Jakarta: Penulis. Diakses dari: https://bit.ly/2SxHbGv

Lembaga Administrasi Negara. (2019). Peraturan Lembaga Administrasi negara tentang Pelatihan Kepemimpinan Administrator (PERLAN No.16 Tahun 2019). Jakarta: Penulis. Diakses dari: https://bit.ly/3b0xNlh

Leslie, J. B. (2009). The leadership gap: What you need, and don't have, when it comes to leadership talent. Greensboro, NC: Center for Creative Leadership.

Lockwood, N.R. (2006). Talent management: driver for organizational success', The Society for Human Resource Management Research Quarterly, pp.2-11.

Melandari, A. N. (2016). Implementasi Kebijakan Pendidikan Dan Pelatihan Kepemimpinan Tingkat Iv Di Badan Kepegawaian Daerah Kota Palu.
Katalogis, 4(9), 137-145.

Nurseha. (2013). Evaluasi Program Pendidikan dan Pelatihan Kepemimpinan Tingkat IV dalam Rangka Peningkatan Kualitas Aparatur di Kabupaten Berau. Universitas Terbuka.

Partnership for Public Service. (2003). The Best Places to Work in the Federal Government. Diakses dari: www.bestplacestowork.org

Pemerintah Republik Indonesia. (1957). Peraturan Peraturan Pemerintah Republik Indonesia Tentang Lembaga Administrasi Negara (PP Nomor 30 Tahun 1957). Jakarta: Penulis. Diakses dari: http://peraturan.go.id/common/dok umen/ln/1957/pp30-1957.pdf

Pemerintah Republik Indonesia. (1972). Keputusan Presiden Republik Indonesia tentang Tanggung Jawab Fungsionil Pendidikan dan Pelatihan (Keppres No.34 Tahun 1972). Jakarta: Penulis. Diakses dari: https://ngada.org/kp34-1972.htm

Pemerintah Republik Indonesia. (1994). Peraturan Pemerintah Republik Indonesia tentang Pendidikan dan Pelatihan Jabatan Pegawai Negeri Sipil (PP No.14 Tahun 1994). Jakarta: Penulis. Diakses dari: https://ngada.org/pp14-1994.htm

Schwartz, J., Bersin, J., \& Pelster, B. (2014). Human Capital Trends 2014 Survey. Retrieved from http://dupress.com/articles/humancapitaltrends-2014-survey-top-10findings/

Rusmulyani. (2015). Efektifitas Penyelenggaraan Diklat Kepemimpinan Pola Baru terhadap Kinerja Aparatur (Studi Kasus Diklatpim IV pada Badan Diklat Provinsi Bali). Proceeding Pertemuan IImiah Tahunan (PIT) Nasional Ke-2 Ikatan Widyaiswara Indonesia (IWI), 80239(152), 3-4.

Sudradjat, E. (2010). Pendidikan Dan Pelatihan Kepemimpinan Sebagai Strategi Pengembangan Sumberdaya Aparatur Untuk Meningkatkan Kinerja. Wacana, 13 No. 1(1), 166-184.

Sujarwo. (2008). Evaluasi Kinerja Penyelenggaraan Pendidikan dan Pelatihan Kepemimpinan Tingkat IV pada Balai Diklat Keagamaan Semarang. Tesis, 221. 
Sulistiyani, Ambar Teguh dan Rosidah. (2009) Manajemen Sumber Daya Manusia. Yogyakarta: Graha IImu.

Wardani, A. K., \& Suryono, A. (2014). DALAM RANGKA MENINGKATKAN KINERJA PEGAWAI (Studi Kasus pada Badan Kepegawaian Daerah Kabupaten Nganjuk). Jurnal Administrasi Publik, 2(1), 134-140.

Wulandari, A. S. (2012). Evaluasi Pendidikan dan Pelatihan Kepemimpinan Tngkat IV Tahun 2011 pada Pusat Pembinaan, Pendidikan dan Pelatihan Badan Pengkajian dan Penerapan Teknologi. Universitas Indonesia.

Yunita, E., Sumanti, R., Sinurat, H. P., Syahputra, H., Afrian, N., \& Febrianto, M. (2017). Kajian Evaluasi Pasca Diklat Kepemimpinan Tingkat II, III, dan IV. 